\title{
Analysis and Diagnosis of the Church of Santiago in Jerez de la Frontera (Spain)
}

\section{Análisis y diagnóstico de la Iglesia de Santiago en Jerez de la Frontera (España)}

\author{
E. Rodríguez-Mayorga ${ }^{(*)}$, E. Yanes-Bustamante ${ }^{(*)}$, A. Sáez-Pérez ${ }^{(*)}$
}

\begin{abstract}
The church of Santiago (Jerez de la Frontera, Spain) has its origin in a small chapel built in the XIII century. Three naves added in the XV century gave rise to the current temple. The church has been modified along the history due to two main reasons: (I) the interest for its enlargement and embellishment and (II) to solve some structural problems documented since the XVII century. The most relevant problems that have affected the structure can be summarized in two partial collapses (1695 and 1956) and the substitution of two columns (1902 and 1928) to prevent new catastrophes. However, at the beginning of the XXI century important damage in columns and walls caused to close the temple and initiate an ample investigation on the church and its structural behaviour. The conclusions of this analysis, together with a preliminary proposal for restoration, are the main goal of this paper.
\end{abstract}

Keywords: Analysis of historical structures; masonry; diagnosis; non-destructive techniques.

\section{RESUMEN}

La Iglesia de Santiago (Jerez de la Frontera, España) tiene su origen en una pequeña capilla del siglo XIII. En el siglo XV se le añadieron tres naves, dando como resultado el templo actual. La Iglesia se ha modificado en determinadas ocasiones debido principalmente a: (I) el interés por ampliarla y embellecerla y (II) solucionar algunos problemas estructurales documentados desde el siglo XVII. De estos últimos, los más relevantes en relación a la estructura pueden resumirse en dos colapsos parciales (1695 y 1956) y la sustitución de dos pilares (1902 y 1928) para evitar otras dos catástrofes. Al inicio del siglo XXI, la nueva aparición de daños en pilares y muros condujo al cierre del templo y al inicio de una investigación sobre el comportamiento estructural de la iglesia. Las conclusiones de este análisis, junto a una propuesta preliminar para su reparación, constituyen el objetivo principal de este artículo.

Palabras clave: Análisis de estructuras históricas; fábrica; diagnóstico; técnicas no destructivas.

(*) Universidad de Sevilla (España).

Persona de contacto/Corresponding author: espe@us.es (E. Rodríguez-Mayorga)

Cómo citar este artículo/Citation: Rodríguez-Mayorga, E., Yanes-Bustamante, E., Sáez-Pérez, A. (2015). Analysis and Diagnosis of the Church of Santiago in Jerez de la Frontera (Spain). Informes de la Construcción, 67(540): e127, doi: http://dx.doi.org/10.3989/ ic.15.030.

Licencia / License: Salvo indicación contraria, todos los contenidos de la edición electrónica de Informes de la Construcción se distribuyen bajo una licencia de uso y distribución Creative Commons Reconocimiento no Comercial 3.o. España (cc-by-nc). 


\section{INTRODUCTION}

The church of Santiago is one of the most important temples from the historical and artistic point of view in the city of Jerez de la Frontera (Spain). Its origin is not clearly documented, but it is thought to be in a small chapel, built during the XIII century and devoted to Santiago Apostle in gratitude for the conquest of the city. This disappeared chapel was erected on to a pre-existent hermitage. This hermitage, reconstructed in the XIV century as the Peace Chapel, constitutes the origin of the church of Santiago (Figure 1).

The construction of the church of Santiago has occurred gradually along history, since it has been enlarged and embellished many times. Figure 1 shows the comparison of the plan of the church in the XVI century and the current plan, where the differences are noticeable. All these modifications have as a result a building which general measurements are approximately $43 \times 25 \mathrm{~m}^{2}$ in plan and $20 \mathrm{~m}$ height at the central nave.

The structure is made of masonry, with columns and walls mostly built with external leaves of sandstone regular blocks and cores of rubble masonry. Attending to materials and constructive systems, exceptions can be found in some columns, due to the repairing and reconstruction works that the structure has undergone along its history and that will be later described in this paper (1).

At the beginning of the XXI century the structure of the temple showed clear decay symptoms and severe damage could be easily observed, with the occurrence of several cracks covering the lower part of walls and columns. The fast and significant advance of such damage led to the closure of the temple in 2005. In this year the causes of the damage began to be analysed in detail, in order to issue a diagnosis prior to the temple restoration.

This paper focuses on the analysis and diagnosis of the church, together with the outline of a preliminary restoration strategy. The first part of the paper covers the historical and geometrical analysis, the characterization of the existing damage and crack patterns, as well as the characterization of the materials employed to build the temple (2). The second part is dedicated to structural analysis, using both limit analysis (3) (4) and the
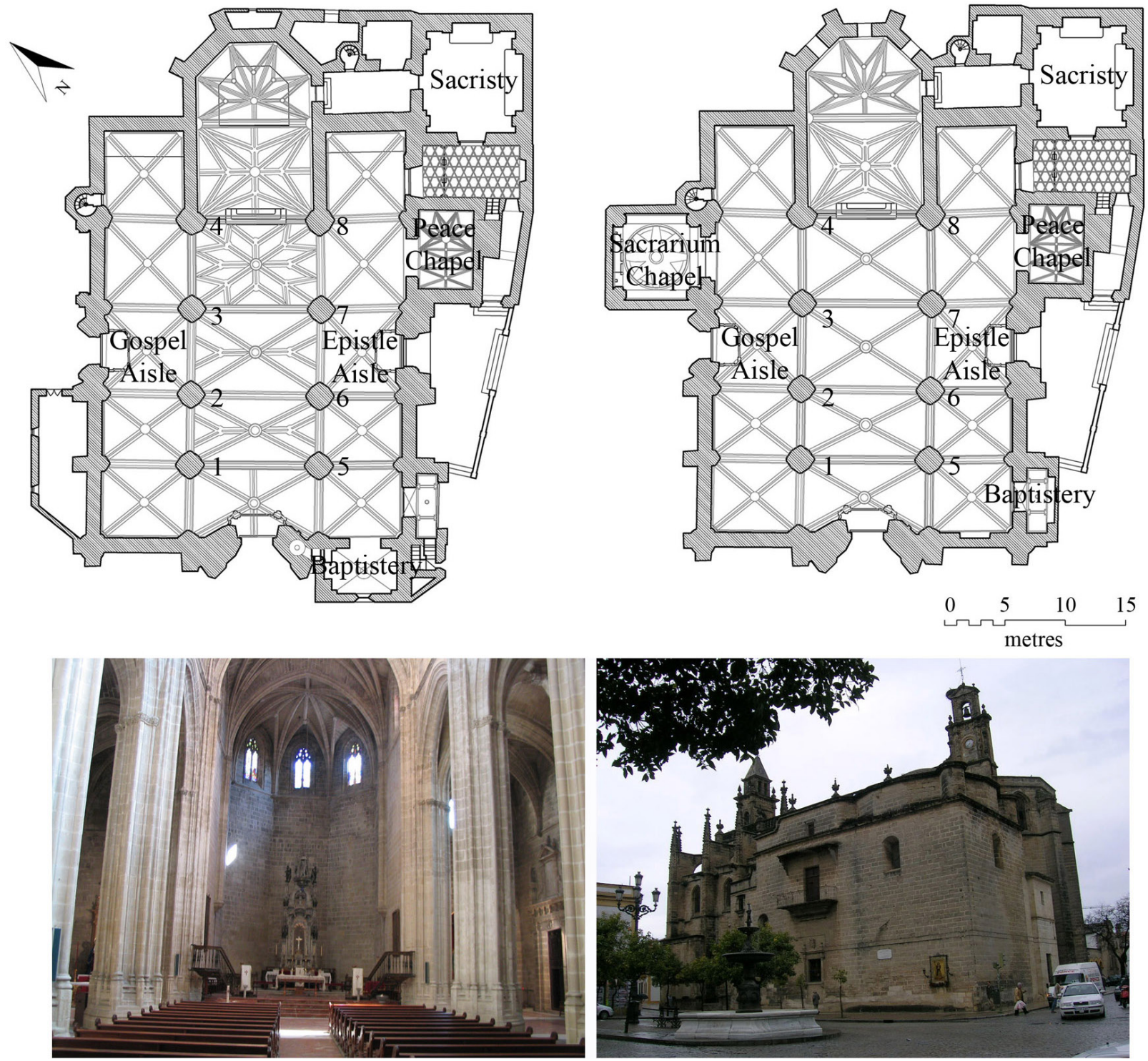

Figure 1. Church of Santiago: Plan in the XVI century (up left), current plan (up right) and some views (down). 
finite element (F.E.) method -see (5) for a comprehensive review-. Once understood the behaviour of the structure, it is possible to determine the causes of damage and decay and further establish the guidelines of a structural intervention (6) (7) that, in this case, demands for urgent measures to prevent the imminent collapse of the structure.

The above analysis led to several issues being identified as the principal causes of the observed structural damage, with the following two being the key aspects: (I) Unbalanced geometry, due mainly to the fact that the current temple has been erected by successive enlargements and additions to the initial chapel, thus lacking of an overall design project; and (II) Rising damp, that constitutes a significant degradation factor for the masonry, magnified by the fact that the church was constructed close to a surface runoff (8).

In the last section of this paper a preliminary plan for the restoration will be outlined. Such restoration is conditioned by some important aspects: (I) First, the emergency for the repair, due to the fact that the structural damage was advancing fast and rising damp was an active degradation factor; (II) Second, the budget for the repair was limited. Therefore, the proposed plan of the restoration has to solve the multiple causes of damage and further satisfy the above requirements.

\section{HISTORICAL ANALYSIS}

The origin of the church of Santiago is not clearly documented. In 1264, after the Reconquest of the city of Jerez de la Frontera from the Arabs by the Castilian king Alfonso X, a new chapel was built devoted to Santiago Apostle. This chapel, currently lost, seems to have been built onto a pre-existing building, the Peace Hermitage. The Peace Hermitage was later reconstructed in the XIV century as the Peace Chapel, so it is the oldest part of the church of Santiago (9). In the XV century, the construction of three Gothic naves attached to the Peace Chapel began, adapting their dimensions to this small building (Figure 1).

Although the main temple was built in the XV century, after the construction of the aisles, the addition and modification of elements continued almost until the XX century. A summary of the main documented modifications, repairs and reconstructions that are relevant for our diagnosis is next described (1) (10) (11) (12):

- In 1661, the construction of a façade-tower over the main door began. Previously, the west end walls had been reinforced to bear this heavy structure.

- In 1695, columns number 2 and 3 collapsed. The reports mainly blamed the bad quality of construction materials and the effect of damp. Their reconstruction began immediately but with a larger section and different decoration in order to distinguish them. This partial collapse also damaged column number 1 , although no further remedial measures were adopted.

- In 1726 a new chapel was added in the Gospel Aisle. To give access to this chapel, currently the Sacrarium Chapel, an arch was opened in the north-side wall. It was constructed without any connection with the original structural masonry of the walls.
- In 1755 a new masonry bell-gable was added on top of one of the presbytery south-side walls. The affected wall was not reinforced.

- In 1879 some works took place in order to renovate the church and adapt it to the artistic trends. The changes related to the structure were:

- Opening of the blind arches of the apse to light the altar.

- Opening of two arches in the presbytery walls to place some choir stalls.

- Elimination of the tiercerons in the central nave for aesthetical reasons.

- Reduction of the section of columns 2 and 3 in order to match them with the original column design.

- In 1902, column number 1 was in danger of collapse, so the column and its foundations were completely substituted by new ones. The new column was much stiffer than the old one since: (I) the column was built with solid section; and (II), the new ashlars were composed by sandstone with improved mechanical properties.

- In 1928, column number 7 showed crushed ashlars in its lower area. The damaged pieces were substituted one to one.

- In 1956, column number 6 collapsed. It was later reconstructed in 1962 using sandstone blocks filled with reinforced concrete. Column number 8 core was consolidated with reinforced concrete too. Additionally, the foundations were braced with reinforced concrete beams and the pots used to lighten the haunches were substituted with honeycomb bonds.

As a consequence of the building history, the structure is heterogeneous in two main aspects: material and geometry. Figure 2 summarizes the modifications described above.

\section{DAMAGE ANALYSIS}

\subsection{Damage survey}

In 2005, the structure of the church was damaged to such an extent that the closure of the temple was mandatory. Significant damage could be observed at a glance. The lower areas of columns were the most important cause for concern since they were cracked and crushed. The most damaged columns were columns number 5 and 7 , while columns number 1 and 8 did not exhibit any defect. Figure 3 illustrates the crack pattern through visual inspection in the columns.

Cracks in walls were significant as well. In almost all walls, cracking and crushing appeared mainly in window corners and arch haunches, as well as in the lower part of the buttresses. Figure 4 summarizes their crack pattern through visual inspection.

Another important issue was rising damp, which affected the bottom part of most walls and columns. Percentage of dampness in lower sections of columns varied from $20 \%$ to $40 \%$, and in some points it reached $75 \%$. As a consequence of dampness, vegetation had grown over the exterior part of the walls damaging and detaching some pieces of stone. 


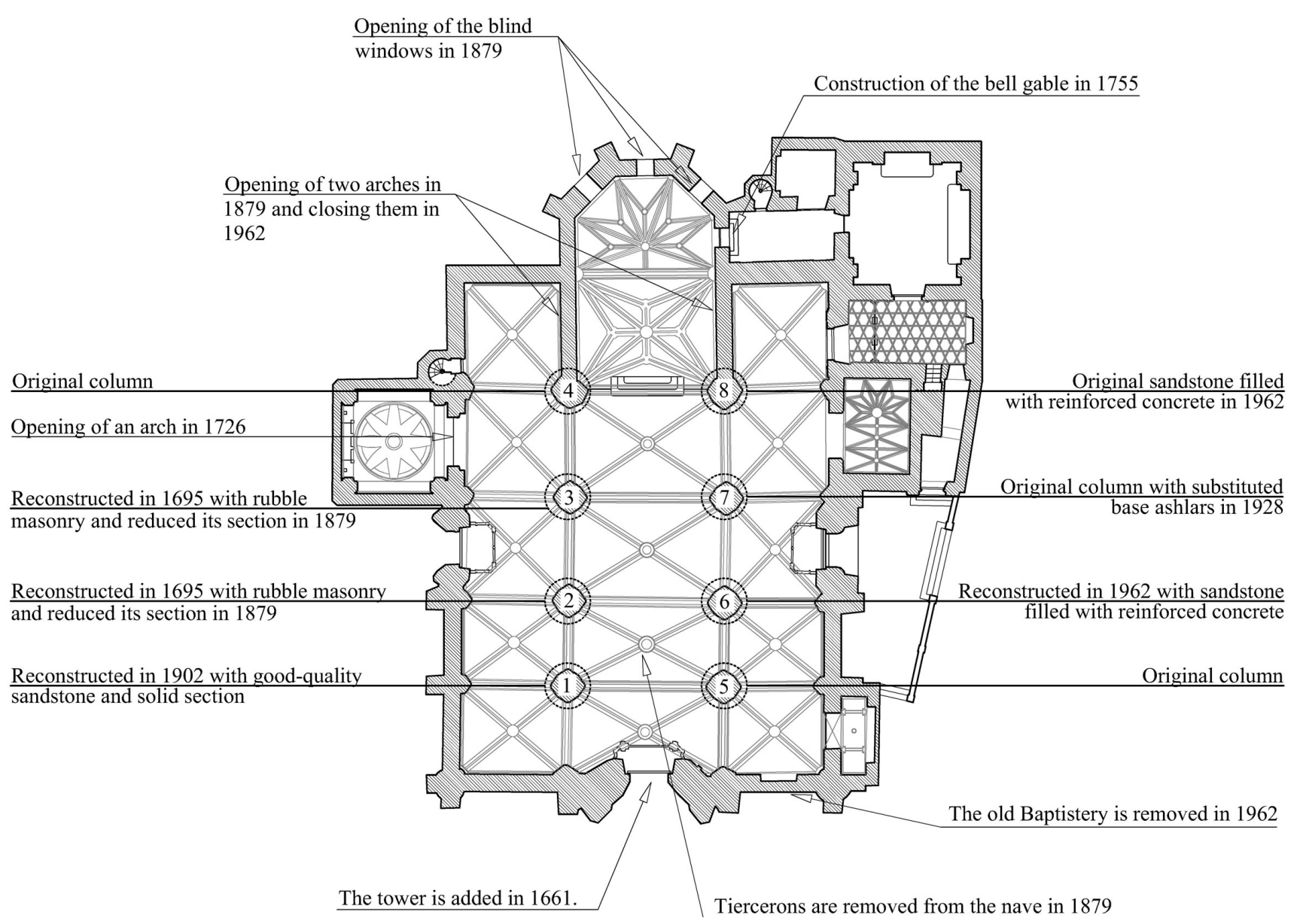

Figure 2. Summary of the works that have happened in Santiago Church and resulting state of the columns.

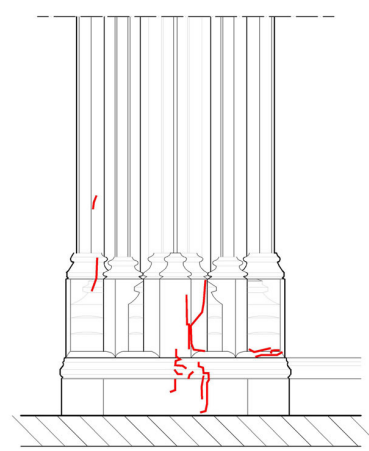

Column 2

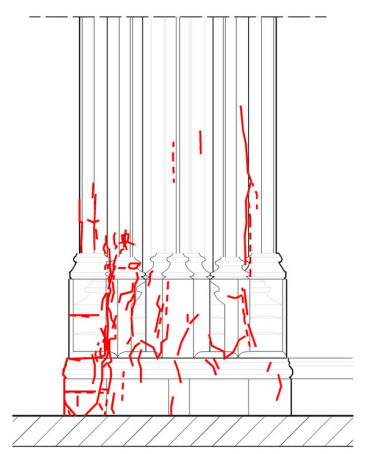

Column 5

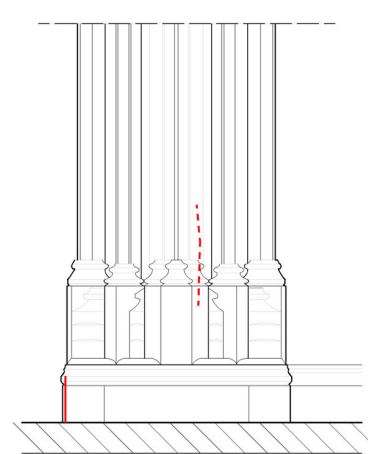

Column 3

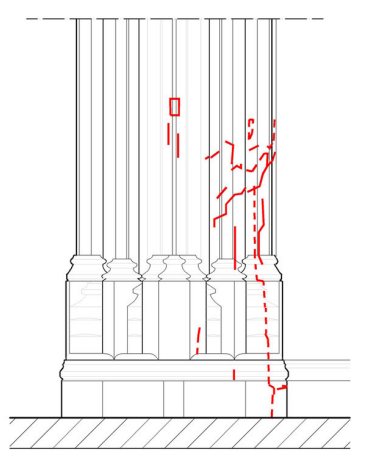

Column 7

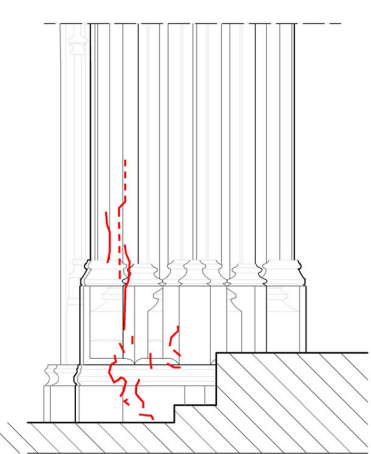

Column 4

Figure 3. Crack pattern in the four lower meters of columns viewed from the nave. 

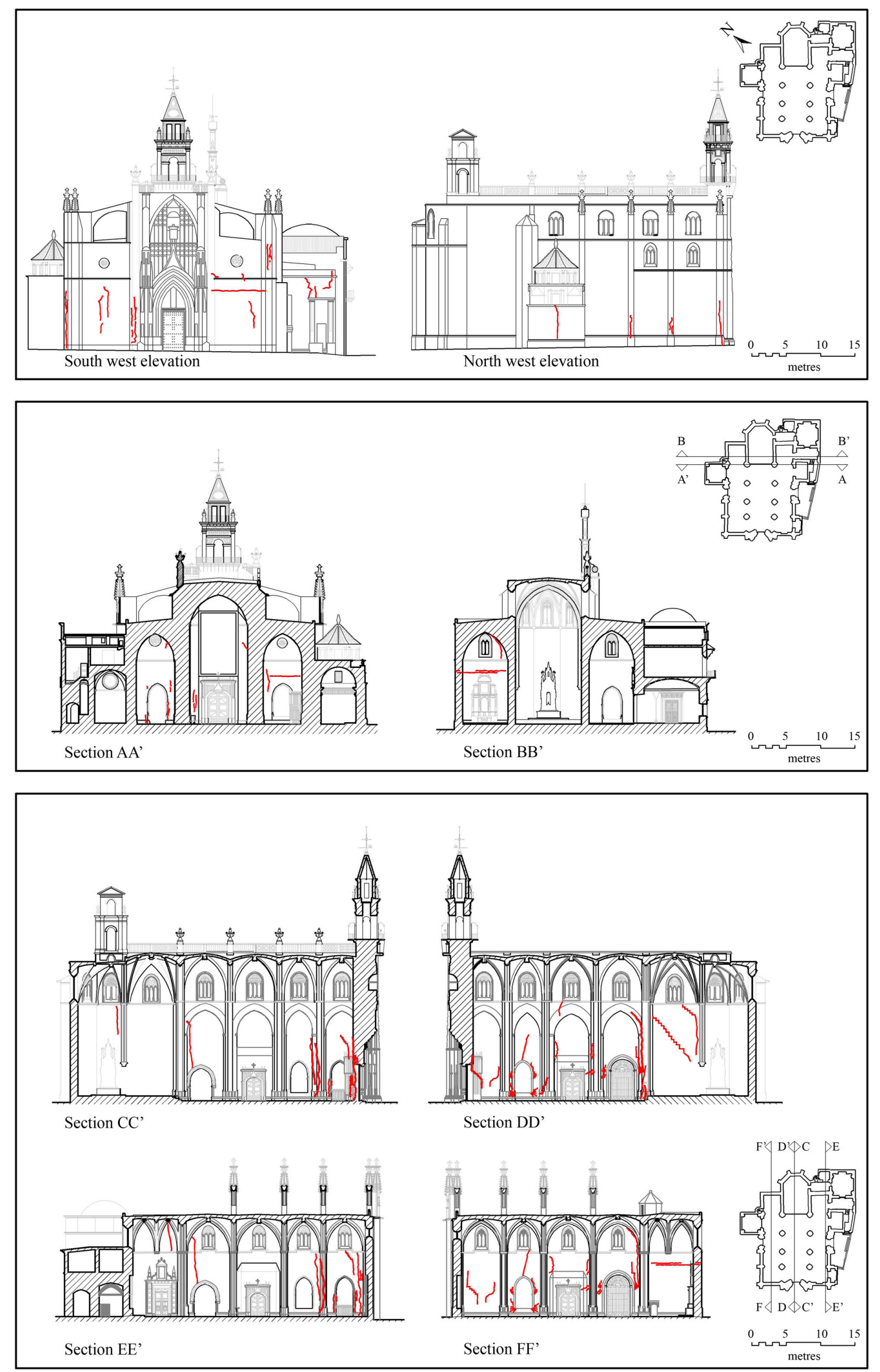

Figure 4. Crack pattern in walls. 


\subsection{Construction Material Analysis}

The structure is built with calcarenite stone blocks filled with rubble masonry. As it has been previously referred, just column 4, column 5 and walls were original (Figure 2). Some tests were carried out to characterize these different materials and to know the internal state of preservation of columns and walls (13).

Geo-radar tests gave qualitative important information about columns and walls. An $800 \mathrm{MHz}$ antenna was used for them. The georradar revealed the inner crack pattern of these elements. Only column number 1 was not internally cracked.

Core samples were extracted from some walls and columns and tested in laboratory. The material is highly porous, ranging its porosity from $18.4 \%$ the column number 1 to the $27.7 \%$ in one of the walls (14). Comparing the resistance values obtained from columns number 1, 3 and 5 for being representative of the materials placed in the different restorations (Figure 2), together with the results obtained from the most damaged walls (Table 1), two main conclusions may be drawn:

- The compressive resistance of all specimens is shortened around a $30 \%$ from dry to water-saturated conditions, thus emphasizing the importance of rising damp as a key deterioration factor.

- Great dispersion is observed in mechanical properties data. The compressive stress of the dry sandstone of columns ranges from 4.7 $\mathrm{MPa}$ (column 1) to $1.7 \mathrm{MPa}$ (column 5). This also occurs in walls, where values range from 3.5 MPa in the main door pilaster to $1.6 \mathrm{MPa}$ in the north-side buttress.

Sonic tests were conducted for all the columns. Recorded velocity values are typical of each type of masonry and provide a qualitative evaluation of the masonry consistency and presence of detachments (2) (15). Triaxial accelerometers capable to register waves with frequencies from $100 \mathrm{~Hz}$ to $6.5 \mathrm{kHz}$ and a piezoelectric trigger were used. The velocity of $\mathrm{P}$ and $\mathrm{S}$

Table 1. Compressive resistance obtained by crushing stone core samples.

\begin{tabular}{|l|l|l|c|}
\hline Sample location & Material & \multicolumn{1}{c|}{$\begin{array}{c}\text { Damp } \\
\text { conditions }\end{array}$} & $\begin{array}{c}\text { Stress } \\
\text { (MPa) }\end{array}$ \\
\hline \multirow{2}{*}{ Column 1 } & Sandstone & Dry & 4.7 \\
\cline { 2 - 4 } & Sandstone & Saturated & 3.2 \\
\hline \multirow{2}{*}{ Column 3 } & Sandstone & Dry & 4.1 \\
\cline { 2 - 4 } & Sandstone & Saturated & 2.9 \\
\hline \multirow{2}{*}{ Column 5 } & Sandstone & Dry & 1.7 \\
\cline { 2 - 4 } & Sandstone & Saturated & 1.4 \\
\hline \multirow{2}{*}{ Main door pilaster } & Sandstone & Dry & 3.5 \\
\cline { 2 - 4 } & Sandstone & Saturated & 2.9 \\
\hline \multirow{2}{*}{ Gospel side buttress } & Sandstone & Dry & 1.6 \\
\cline { 2 - 4 } & Sandstone & Saturated & 1.2 \\
\hline \multirow{2}{*}{ Baptistery wall } & Sandstone & Dry & 3.1 \\
\cline { 2 - 4 } & Sandstone & Saturated & 2.1 \\
\hline
\end{tabular}

waves crossing the column sections were measured in three different planes (0.5, 3.5 and $5.5 \mathrm{~m}$ from the soil level) in order to identify the influence of rising damp in the masonry. These data are summarized in Figure 5. Two main conclusions may be drawn:

- In general, lower values of wave velocities are recorded at the inferior part of the columns, due to the deterioration induced by rising damp. Exceptions can be found in columns 7 and 8 due to its history: the lower ashlars of column 7 were substituted and column 8 was filled with reinforced concrete (Figure 2).

- Large differences exist among the measured velocities. For instance, the values of $\mathrm{P}$-waves for the lower sections range from $2186 \mathrm{~m} / \mathrm{s}$ (column 5) and $4279 \mathrm{~m} / \mathrm{s}$ (column 1). This heterogeneity was also expected due to the historical evolution of the structure (Figure 2).

A second set of tests was related to foundations. The subsoil was analysed through the drilling of two boreholes and the prospection with geo-radar. Both tests highlighted the superficiality of groundwater level, about $2 \mathrm{~m}$ deep, revealed that the consistency of the soil was hard and discarded any problem related to foundations (13).

\section{GEOMETRICAL ANALYSIS}

The structure of the church of Santiago is mainly Gothic. Gothic architecture is characterised by the relationship between geometry and equilibrium (16) (17). However, a geometrical analysis of the church of Santiago reveals some geometric irregularities which deeply affect its structural behaviour. This geometric analysis has been based on a survey carried out by classic methods. These irregularities can be listed as follows (Figures 1 and 6):

- Longitudinally, distances between columns are significantly different, ranging from $5.89 \mathrm{~m}$ (columns 1-2) to $7.39 \mathrm{~m}$ (columns 3-4) measured between the axis of columns. This leads to different geometries of arches and subsequently to different values and directions of thrust, as well as vertical loads. Transversally, the spans of the aisles are more similar: $8.01 \mathrm{~m}$ in the Epistle side in comparison to $8.37 \mathrm{~m}$ in the Gospel side.

- Flying buttresses are missing in the two planes closer to the apse. The buttress in the east end wall is also missing and the buttress attached to the Sacrarium chapel is longitudinally drilled to host the spiral stairs (Figure 1).

- The geometry and position of flying buttresses make them unable to balance the vaults. Therefore, they become exclusively decorative elements (18) and for the drainage of the roofs.

- Pinnacles are placed only over the columns number 5, 6, 7 and 8 and missing for the rest of columns.

- Distribution of the constructions at both sides of the church is different.

These irregularities observed in the geometry will lead to the existence of unbalanced forces as the structural analysis will point out in the next section. 
Velocity of sonic waves in columns

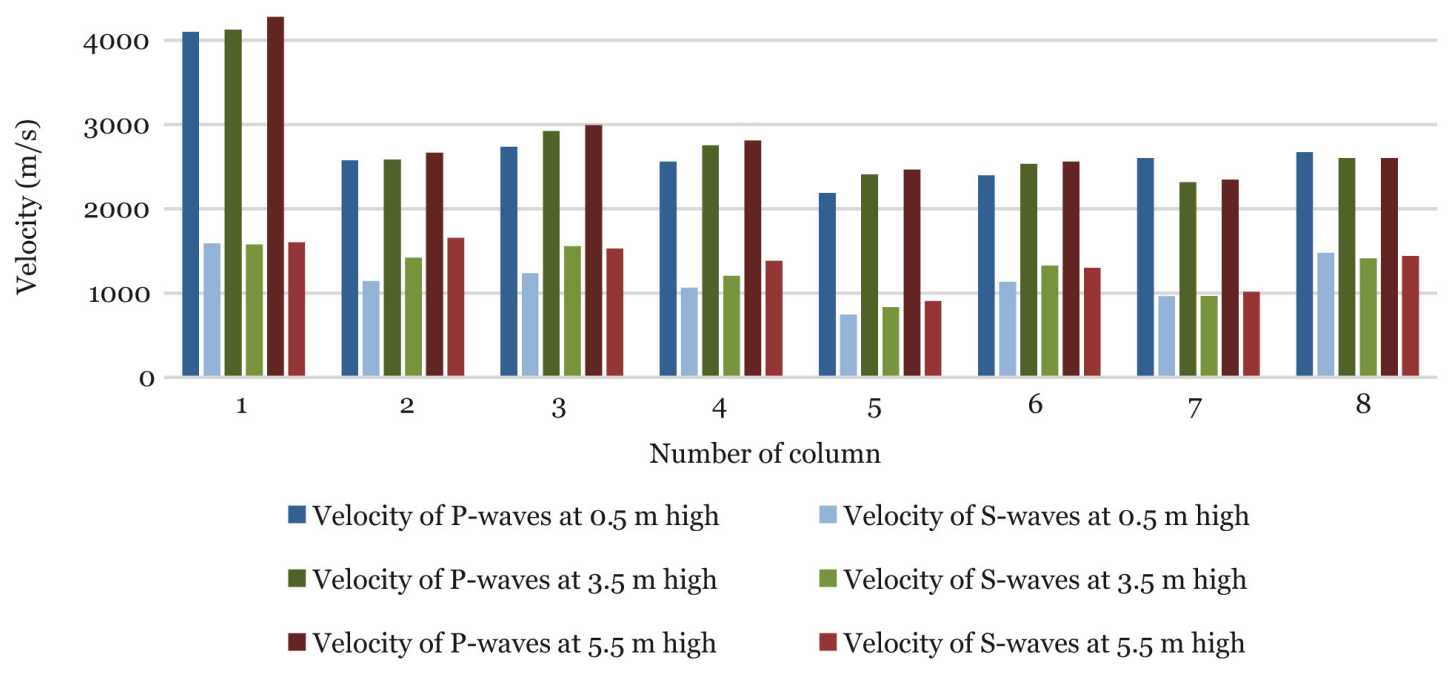

Figure 5. Chart summarizing the velocities of $\mathrm{P}$ and $\mathrm{S}$ waves in columns.
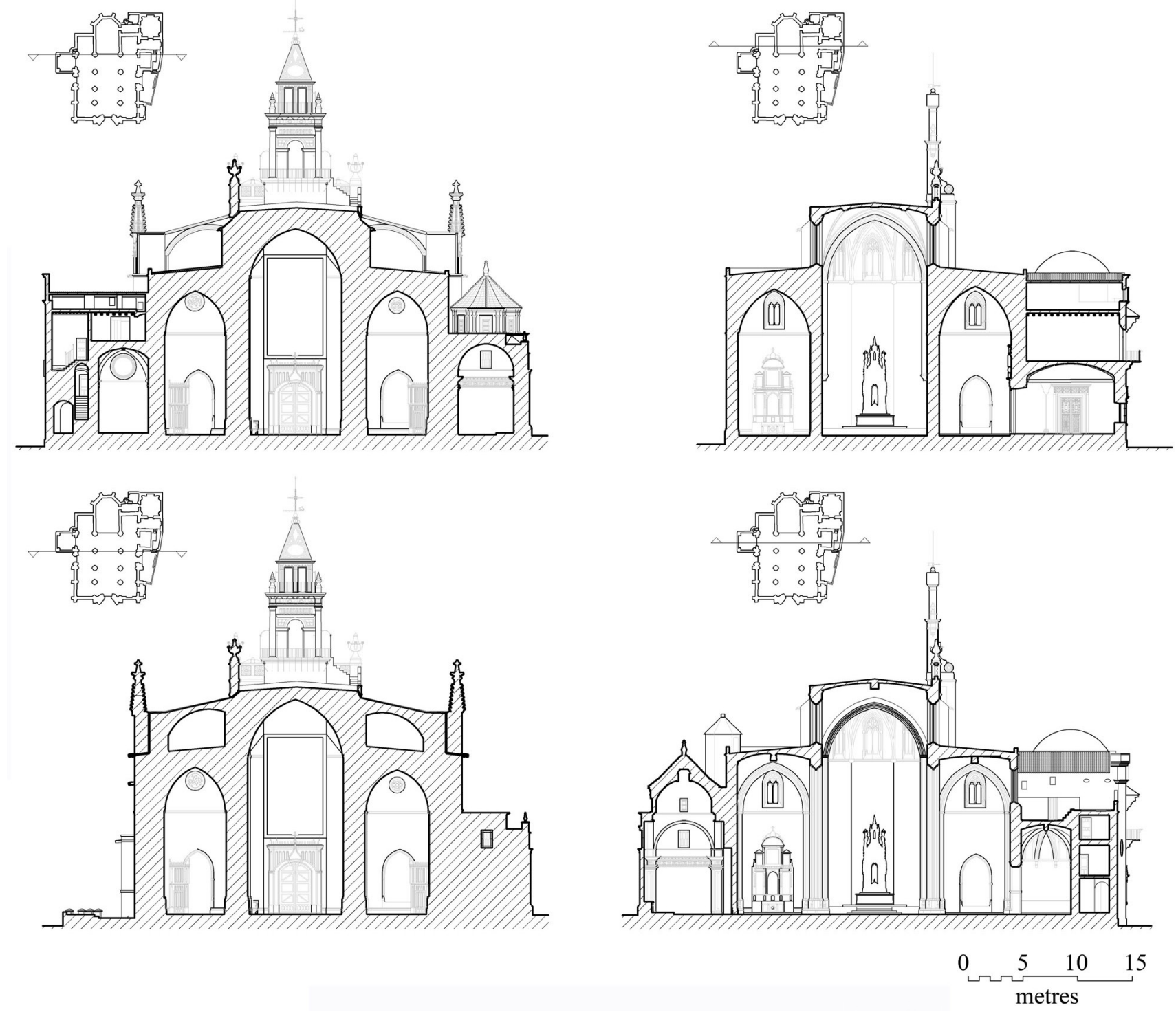

Figure 6. Church of Santiago: Transversal sections. 


\section{STRUCTURAL ANALYSIS}

\subsection{Limit analysis: thrust line analysis}

The thrust line analysis is a classical tool for the assessment of the equilibrium in masonry structures (4) (5) (16). In this paper it will be used to check the influence of the previous geometrical analysis on the temple structural behaviour. To this end, the transversal plane crossing columns 2 and 6 will be selected as a standard representative section. Since just the geometry is to be tested, the assumptions of no tensile resistance, infinite compressive resistance and no sliding may be adopted for this purpose.

The complete analysis of the thrust line in the plane of the columns 2 and 6 is depicted in Figure 7. It may be observed that although the thrust line is inside the structure, it does not lie always inside the middle third. This is due to the geometrical irregularities described in the previous section and it is one of the causes for the observed cracks in structural elements. Therefore, the malfunctioning of the structure is partially caused by the geometry, since:

- The buttresses thickness is too small to balance the load from the vaults. This problem is further worsened by the position of the pinnacles.

- The dead loads over the columns are different.

The position of the flying buttresses is another point to check with this limit analysis. Although their position seems to be quite high to balance the vault load, a comparison of the current situation and a hypothetical one where the flying buttress would not exist was carried out. The result of this comparison is depicted in Figure 8. It clearly shows that the position of the flying buttress is misconceived as a structural element, since both thrust lines are almost coincident.

\subsection{Finite element analysis}

Following the two dimensional thrust line analysis, a global finite element (FE) analysis of the structure was performed in order to check the $3 \mathrm{D}$ behaviour of the structure. This FE model may further take into account both the irregular geometry as well as the heterogeneity detected in the properties of the materials.

A simplified finite element model using 4-node shell and 2-node beam elements was carried out with the ANSYS ( Multiphysics ${ }^{\mathrm{TM}}$ software (19). The resulting model has 48.880 elements and 41.487 nodes, as Figure 9 illustrates. Only dead loads (including the vault infill) were considered for this preliminary calculation. Linear elastic analysis was done assuming it as a simplification (20) to better understand the global behaviour of the structure. Material properties for the calculations were obtained from the tests (13). FE is a tool that has been successfully applied to masonry analysis. Although the use of solid elements and material non-linearities would have been more suitable for this kind of structures (21), due to the fact that the analysis should be done over the whole structure and that the objective was obtaining qualitative global characteristics of the behaviour of the temple, just a preliminary simplified model was done. At any event, in the final part of this section, the validity of the analysis is verified by comparing the FE model behaviour with the observed damage patterns.

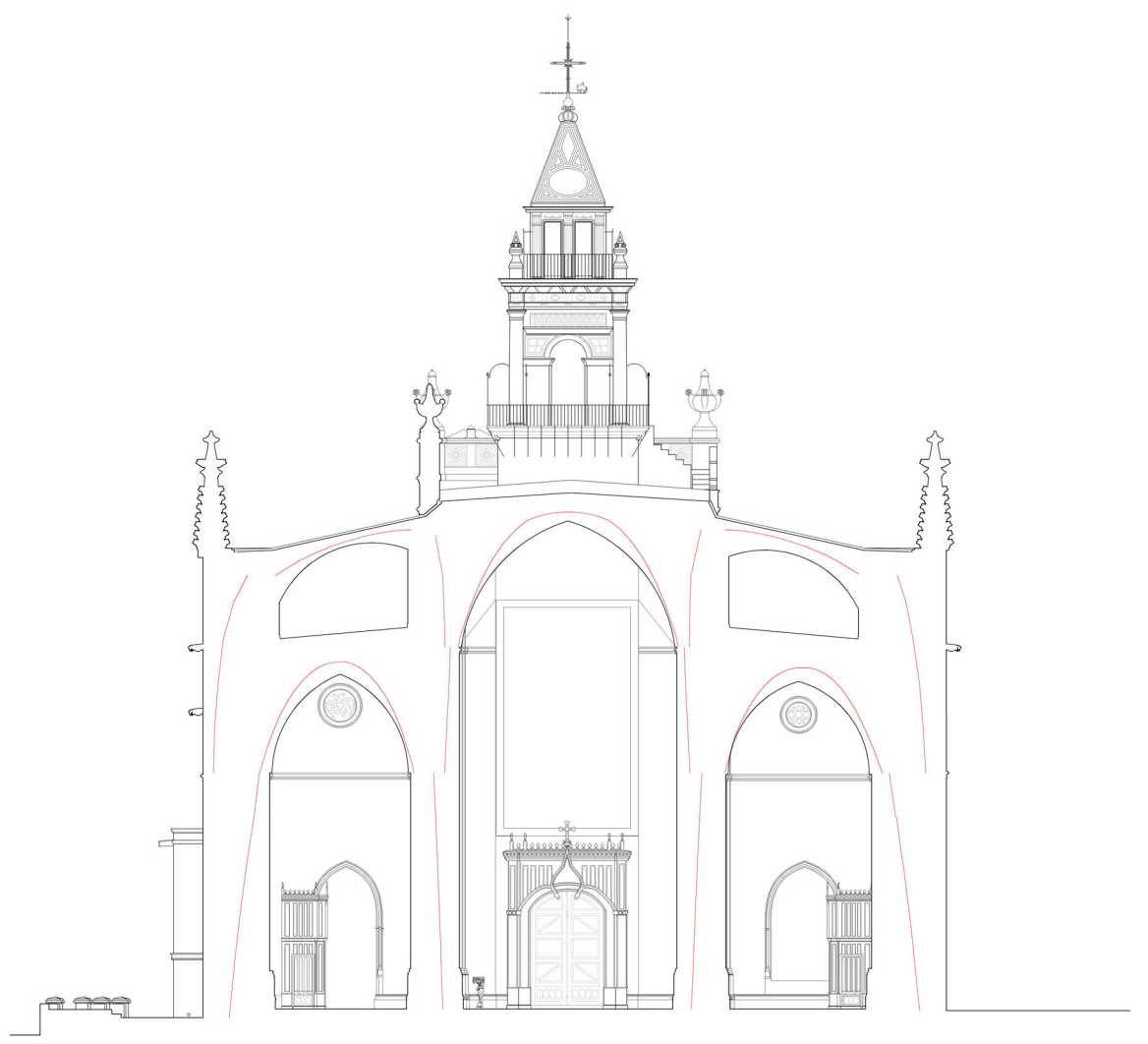

Figure 7. Thrust line analysis of the transversal section including columns number 2 (right) and 6 (left). 


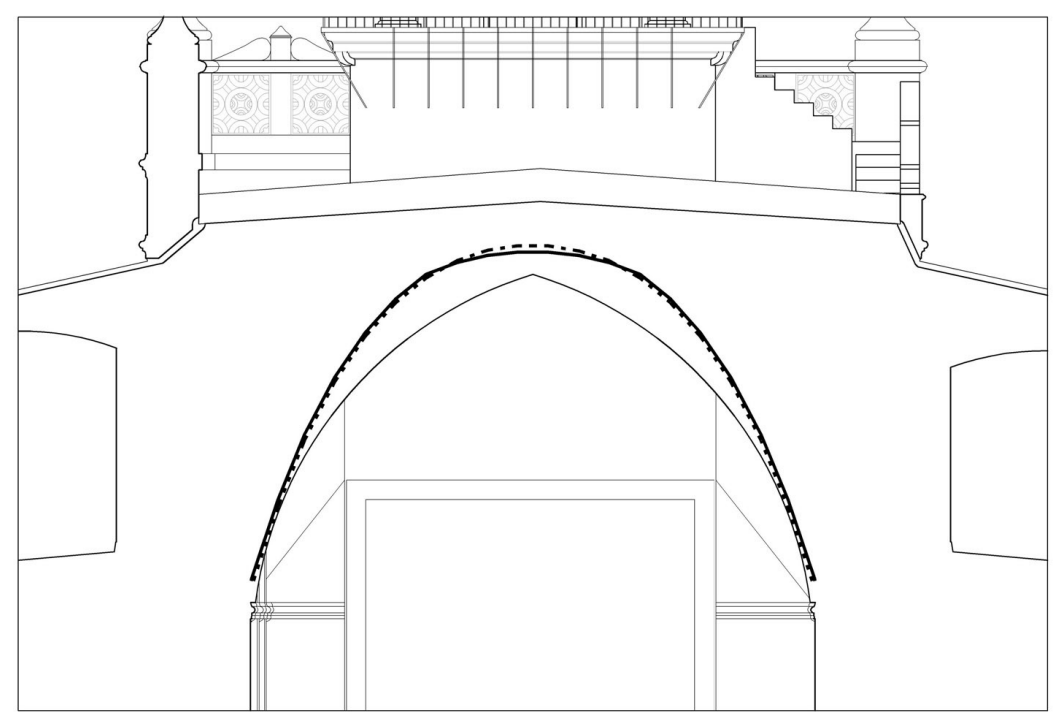

With flying buttress

Without flying buttress

Figure 8. Comparison of the behaviour of the central arch with and without flying buttress.

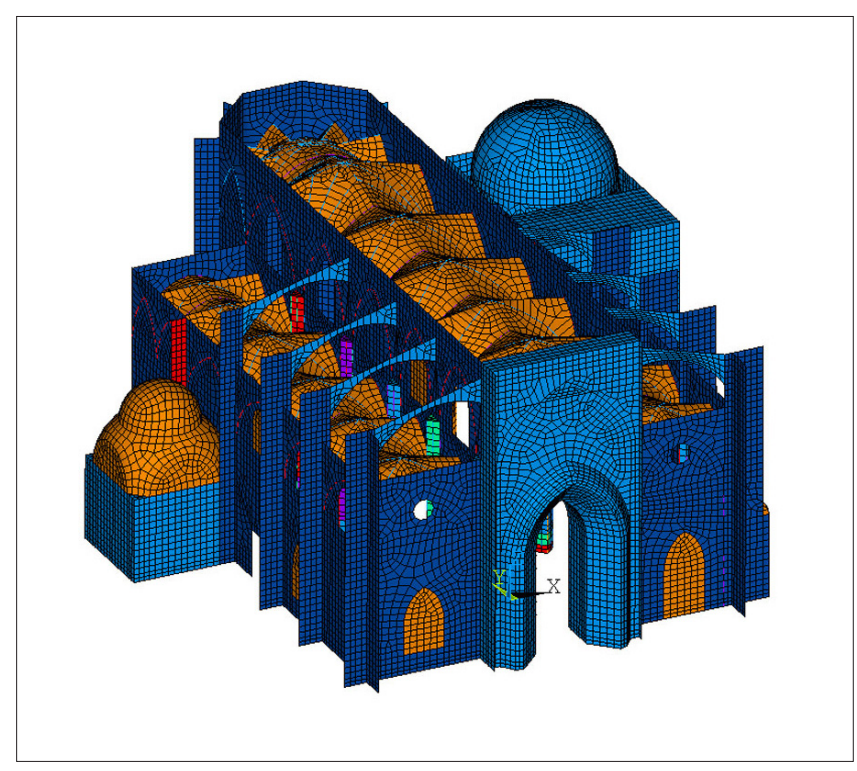

Figure 9. Numerical simplified model of the church of Santiago.

As pointed out above, the FE results were favourably compared with the plane thrust line analysis and the observed crack pattern, thus validating the model. For instance, Figure 10 shows the FE analysis of the same plane considered for the previous thrust line analysis (columns 2 and 6), where the concentration of vertical stresses in the exterior area of the buttress close to column 2 (1.045 MPa in the lower sections) can be easily identified. The compressive test carried out to this buttress stone led to characteristic compressive resistance values from 1.6 MPa to 1.2 MPa in dry and saturated conditions, respectively (Table 1). This fact explains the cracking observed in this area (as shown in Figure 4).

Further results from the F.E. analysis are depicted in Figures 11 and 12. An unsymmetrical deformed shape can be observed, with a general movement of the structure towards the Gospel side and the west-end (Figure 11) which is coherent with the insitu observations. These irregularities may also be observed as the vertical displacements are concerned. Such values are smaller in the west end, provided the columns are closer in this area and, consequently, the loads the columns bear are also smaller. The heterogeneous behaviour of the church due to different materials and spans of arches is illustrated in Table 2. Table 2 summarizes the vertical reaction loads obtained from the F.E. model for each column, as well as the percentage of the total load that each reaction implies. Such resulting loads depend on both the position of the column and its material. This table also reflects the maximum values of stresses in the columns, leading to values close to the compressive resistance, in particular regarding the columns with original material (columns 4, 5 and 7).

Therefore, the F.E. model has been validated through the favourable comparison with the damage exhibited by the church and it constitutes a valid tool to better understanding the temple structural behaviour. Although the F.E. model does not take into account the constructions phases, it permits to draw qualitative conclusions and, in fact, it will be used in next section to qualitatively anticipate the effect of the proposed remedial measures.

Table 2. F.E. results in terms of loads and stresses obtained for the columns of the church of Santiago.

\begin{tabular}{|l|r|c|c|}
\hline $\begin{array}{l}\text { Column } \\
\text { number }\end{array}$ & $\begin{array}{c}\text { Vertical } \\
\text { reaction } \\
\text { (kN) }\end{array}$ & $\begin{array}{c}\text { \% of the total } \\
\text { load withs- } \\
\text { tand by each } \\
\text { column }\end{array}$ & $\begin{array}{c}\text { Maximum com- } \\
\text { pressive stress } \\
\text { o in the shaft } \\
\text { (N/mm })\end{array}$ \\
\hline 1 & 3143.2 & 14 & 1.64 \\
\hline 2 & 2496.1 & 11 & 1.28 \\
\hline 3 & 2810.3 & 12 & 1.51 \\
\hline 4 & 3129.4 & 14 & 1.62 \\
\hline 5 & 2037.1 & 9 & 1.09 \\
\hline 6 & 3103.1 & 14 & 1.64 \\
\hline 7 & 2623.5 & 12 & 1.40 \\
\hline 8 & 3220.1 & 14 & 1.82 \\
\hline TOTAL & $\mathbf{2 2 5 6 2 . 8}$ & $\mathbf{1 0 0 \%}$ & \multicolumn{1}{|c|}{} \\
\cline { 1 - 3 } & & \multicolumn{2}{|c|}{}
\end{tabular}




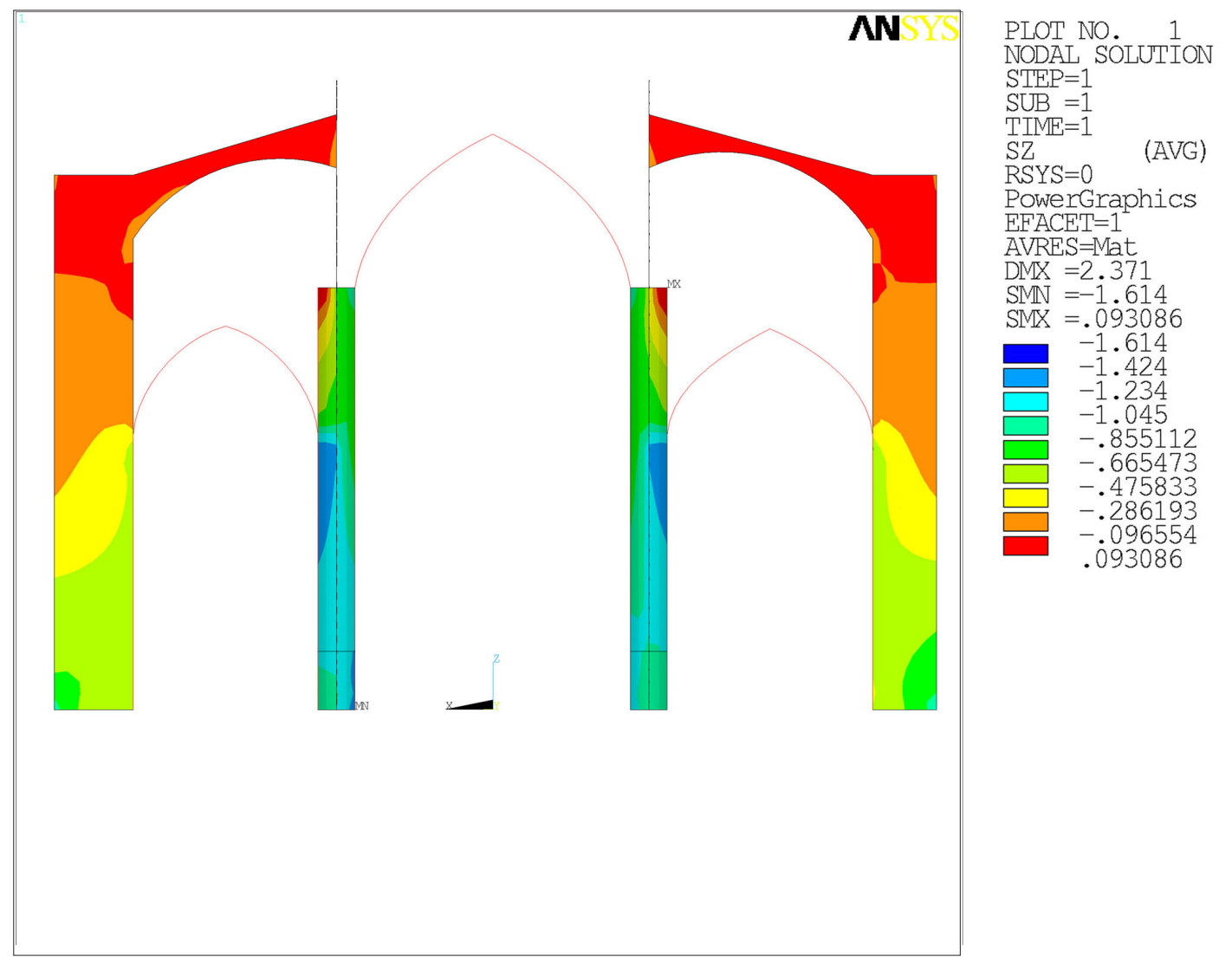

Figure 10. Values of the vertical stresses in MPa of the plane crossing columns 2 (right) and 6 (left).
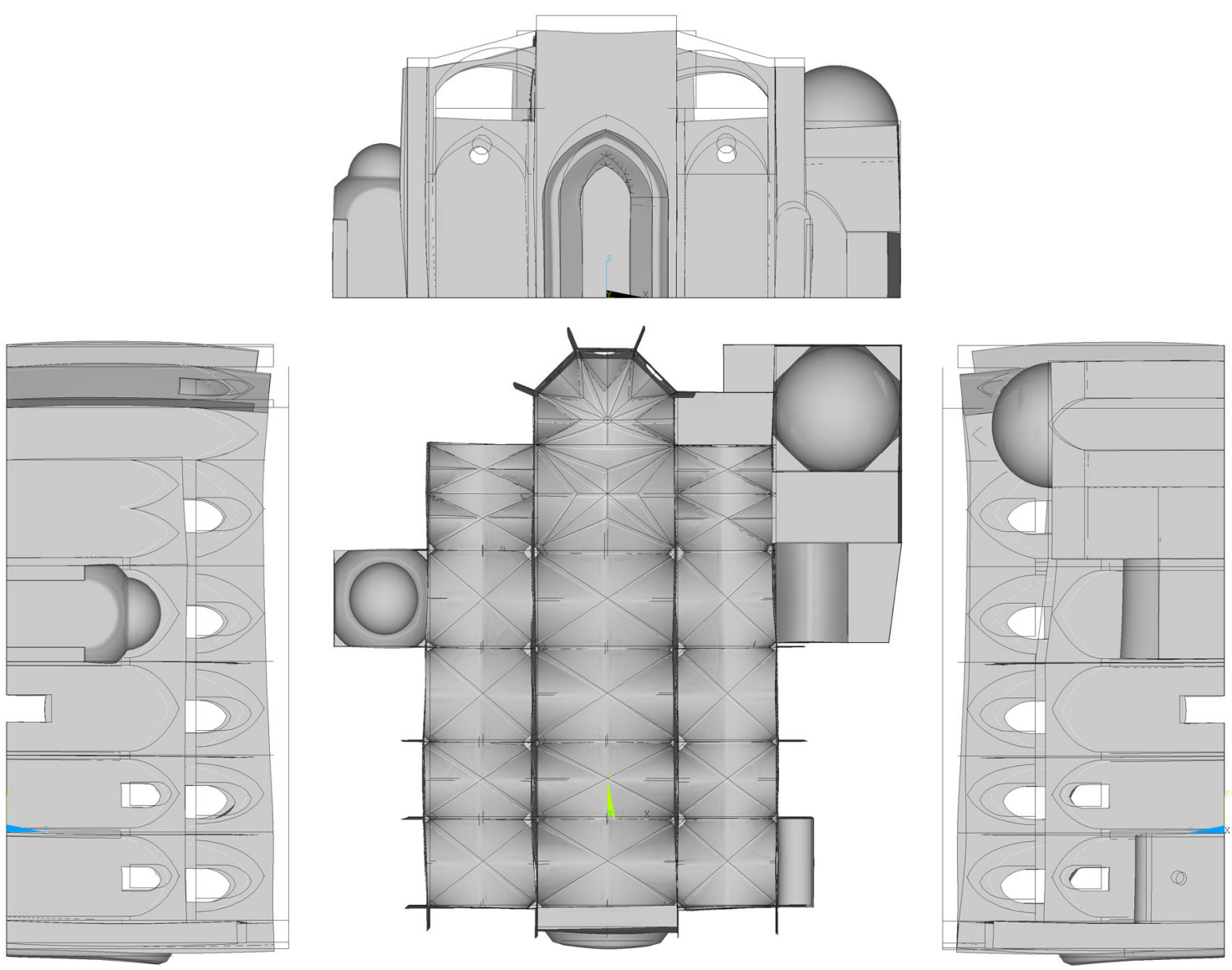

Figure 11. Deformed shape obtained from the calculation. Displacement scale factor 1500. 

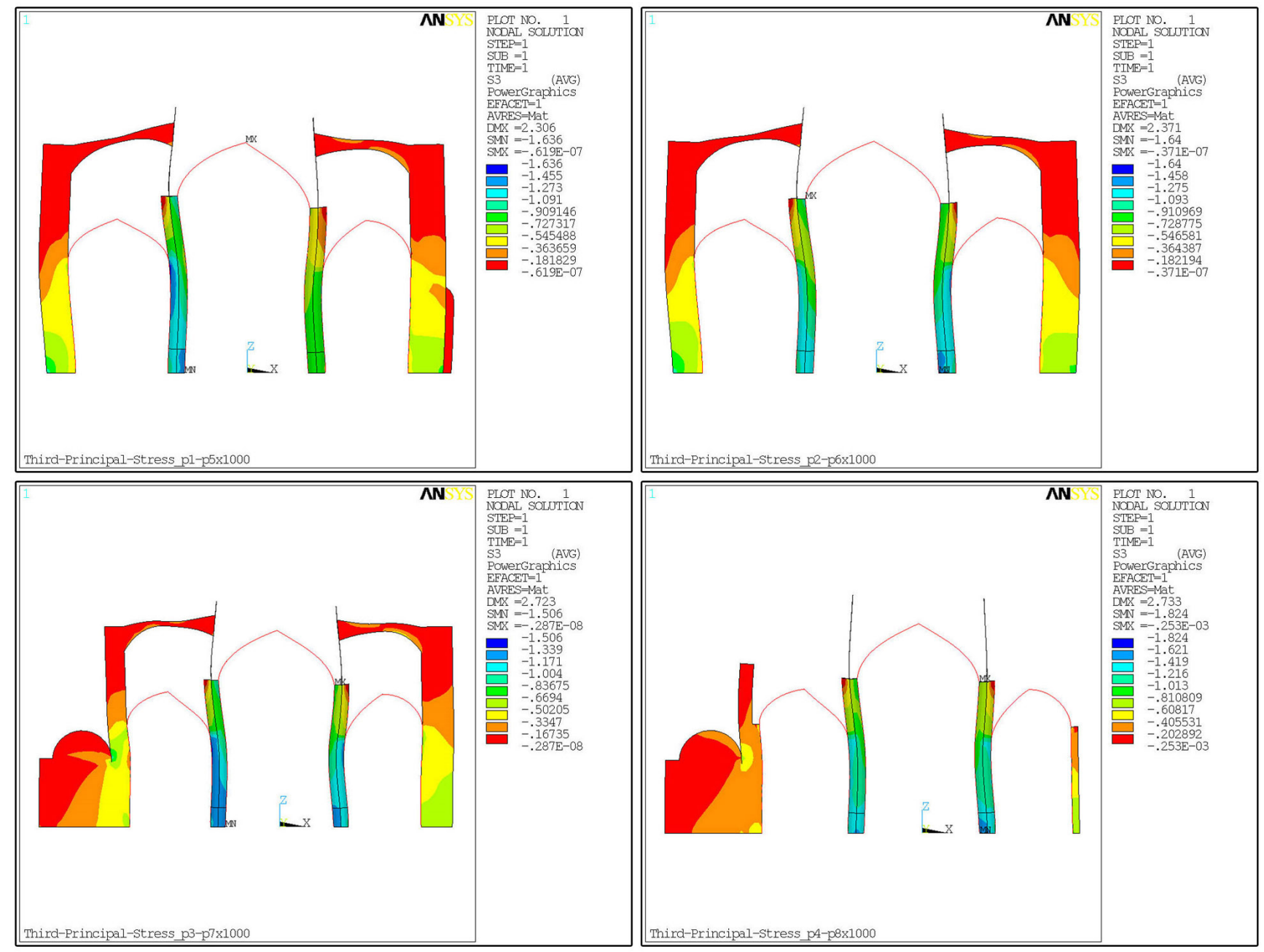

Figure 12. Third principal stresses (compression) obtained for the planes of the columns 1 and 5 (up left); 2 and 6 (up right); 3 and 7 (down left); 4 and 8 (down right). View from the west end. Values in MPa.

\section{DIAGNOSIS AND PLAN OF THE RESTORATION}

According to the results obtained from the analysis shown before, a diagnostic may be established on the causes for the structural problems that the church of Santiago exhibits:

- The material was deteriorated due mainly to the effect of rising damp. Rising damp has the effect of shortening the masonry compressive resistance up to $30 \%$. The dampness content is higher in the lower sections, which are those that are bearing larger stresses. Water ground level is quite superficial, so the effect of rising damp has been continuous along time.

- The materials the structural elements are made of are different in each of them. This heterogeneity is caused by two reasons. Firstly, because of the repairs and reconstructions that occurred in the past; secondly, because of rising damp, that is producing differences among the properties of the columns and between the properties of lower and upper sections in the same column. The different stiffness of the columns causes a clear dispersion on their load bearing demands.

- The geometry presents some original misconceptions and problems due to the gradual enlargement of the church.
Bearing in mind all these items, the remedial measures should be aimed at consolidating the material, so that it becomes able to cope with the stresses that receives and contributes to reduce the heterogeneous behaviour of the columns. Furthermore, this consolidation would lead to a more balanced distribution of loads over the columns because all of them would have similar stiffnesses. Another point to correct would be aimed at controlling rising damp, thus preventing the degradation of the masonry.

Not many techniques are available to consolidate the columns without modifying the aesthetic appearance of the monument. In this case, there were also two additional problems: the available budget was quite limited and there was a clear emergency to repair the structure due to its unsafe situation. A similar situation is analysed in (22), where grout injection with sleeve port pipe was concluded as an appropriate repairing technique, since the injection in consecutive phases allows the application of higher pressures than in the traditional way to inject. This results in an almost complete homogenization of the injected element. Grout injection with the sleeve port pipe technique combines the effectiveness of grout injection as a way to consolidate structures (23) (24) (25) (26) and the ability to improve the mechanical properties of the grouted material that the injection with the sleeve 

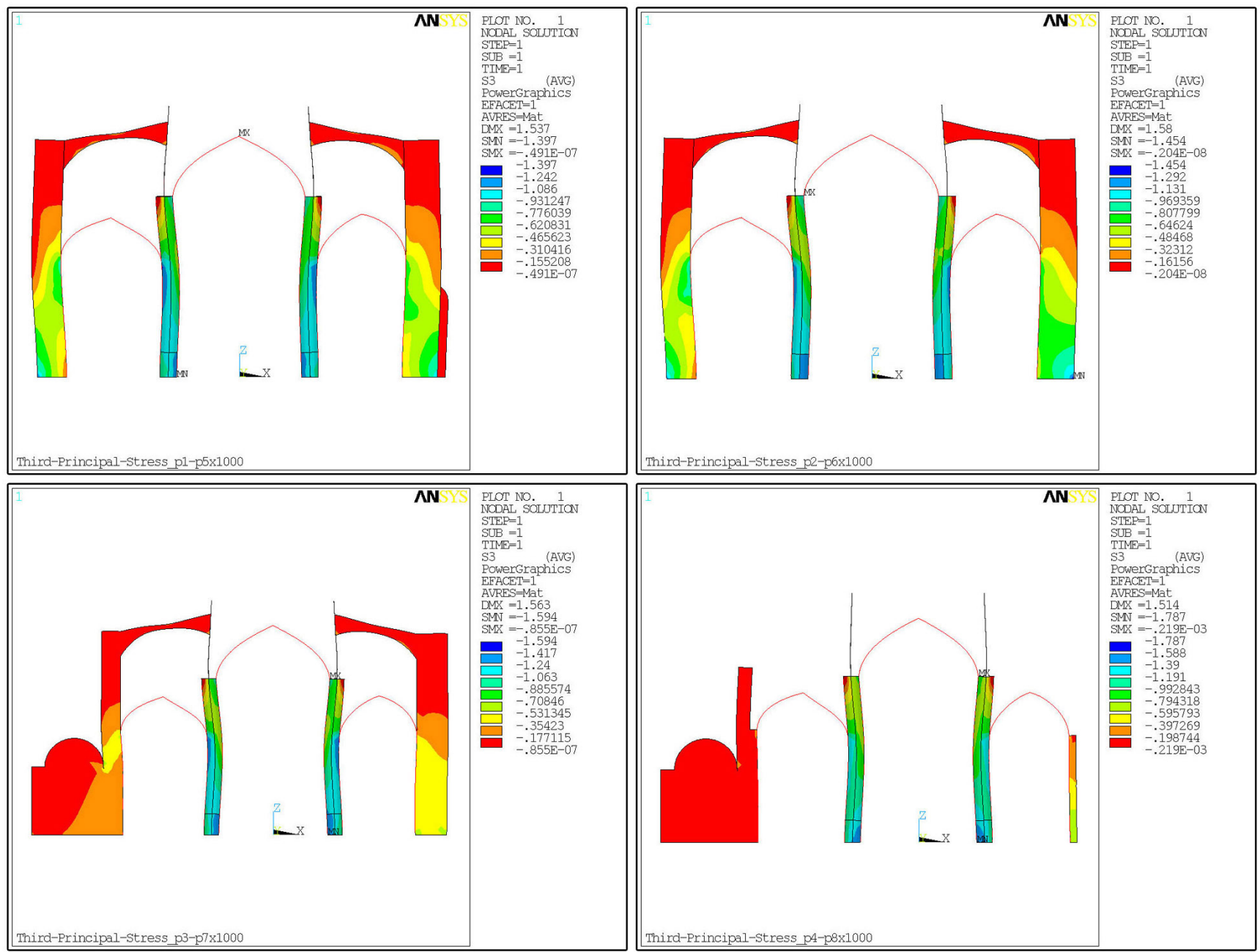

Figure 13. Third principal stresses (compression) obtained for the planes of the columns 1 and 5 (up left); 2 and 6 (up right); 3 and 7 (down left); 4 and 8 (down right) in an ideal situation of good-properties masonry. View from the west end. Values in MPa.

port pipe presents (27) (28). Grout injection with sleeve port pipe is a technique mainly developed for soil consolidation, many times used to expel water from the subsoil. In this situation it also could be useful to prevent rising damp if it were applied under the foundations level.

To check the potential benefits of the consolidation and homogenization of the material through grout injection, a new calculation was performed using the same F.E. model developed in section 5.2 (Figure 9), but setting all the material properties to match those of column number 1 . Column 1 is adopted as reference since, although it is not an original one but reconstructed, it presents the largest resistance values and the basic aim would focus on homogenising the mechanical properties of all the columns. The results in terms of stresses improve, as it may be seen by comparison of results in Figures 12 and 13. Table 3 is similar to Table 2 with the values obtained from the calculations in this hypothetical situation of a homogenized material. The favourable effect of consolidation and homogenization can be easily checked by comparison of Tables 2 and 3. The load values that each column has to bear are more homogeneous than in the initial situation and the values of expected stress levels are more similar among columns. Although, due to the geometrical irregularities that cannot be corrected, some heterogeneity in these values still persists. However, the improvement of the materials after grout injection makes possible for columns to support the loads that they receive.

Table 3. F.E. results in terms of loads and stresses obtained for the columns of the church of Santiago in an ideal homogeneous situation.

\begin{tabular}{|c|c|c|c|}
\hline $\begin{array}{l}\text { Column } \\
\text { number }\end{array}$ & $\begin{array}{l}\text { Vertical } \\
\text { reaction } \\
\quad(k N)\end{array}$ & $\begin{array}{l}\text { \% of the total } \\
\text { load withstand } \\
\text { by each column }\end{array}$ & $\begin{array}{c}\text { Maximum } \\
\text { compressive } \\
\text { stress } \sigma \text { in the } \\
\text { shaft }\left(\mathrm{N} / \mathbf{m m}^{2}\right)\end{array}$ \\
\hline 1 & 2650 & 11 & 1.40 \\
\hline 2 & 2750 & 12 & 1.29 \\
\hline 3 & 2930 & 12 & 1.58 \\
\hline 4 & 3360 & 14 & 1.58 \\
\hline 5 & 2690 & 11 & 1.34 \\
\hline 6 & 2790 & 12 & 1.29 \\
\hline 7 & 2990 & 13 & 1.59 \\
\hline 8 & 3410 & 15 & 1.79 \\
\hline TOTAL & 23570 & $100 \%$ & \\
\hline
\end{tabular}




\section{CONCLUSIONS}

This paper details a case study regarding the analysis and diagnosis of a historical masonry structure, namely the church of Santiago (Jerez de la Frontera, Spain), that exhibits important damage, has precedents of partial collapses along history and demands for urgent safeguard measures to avoid its imminent collapse. A diagnosis has been achieved as the conclusion to a deep analysis covering (I) historical aspects together with (II) a geometric analysis, (III) material characterization via several on site and laboratory testing techniques, (Iv) damage and crack pattern survey, plus (v) structural analysis by both limit analysis and a F.E. model.

These studies revealed an irregular and unbalanced geometry originated by the way the temple has been built. Such geometrical problems have been further confirmed by the structural analyses conducted.
The tests performed have confirmed the low resistance and heterogeneity of the materials in the structure and have highlighted the rising damp as one of the key deteriorating factors. To this end, a preliminary consolidation proposal has been made, in the last part of the paper, based on the use of grout injection with sleeve port pipe in order to homogenise the structural properties of all columns and walls, plus grout injection of the soil in order to diminish the effect of rising damp on the masonry. This way, although the problems derived from the geometrical misconceptions would be obviously still present, its effects in terms of undesirable efforts on the columns could be born.

\section{ACKNOWLEDGMENTS}

This work was partially supported by the Junta de Andalucía (project P12-TEP-2068). The financial support is gratefully acknowledged.

\section{REFERENCES}

(1) Álvarez Luna, A., Guerrero Vega, J., Romero Bejarano, M. (2005, 25-29 January). Los problemas estructurales de la Parroquia de Santiago de Jerez de la Frontera. In Cuarto Congreso Nacional de Historia de la Construcción (pp. 35-47). Cádiz: Ed. S. Huerta.

(2) Binda, L., Saisi, A., Tiraboschi, C. (2000). Investigation procedures for the diagnosis of historic masonries. Constructions and Buildings Materials, 14(4): 199-233, doi: http://dx.doi.org/10.1016/So950-0618(oo)ooo18-0.

(3) Heyman, J. (1966). The stone skeleton. International Journal of Solids and Structures, 2(2): 249-256, doi: http:// dx.doi.org/10.1016/0020-7683(66)90018-7.

(4) Huerta, S. (2005). Mecánica de las bóvedas de fábrica: el enfoque del equilibrio. Informes de la Construcción, 56(496): 73-89, doi: http://dx.doi.org/10.3989/ic.2005.v57.i496.496.

(5) Roca, P., Cervera, M., Gariup, G., Pela, L. (2010). Structural Analysis of Masonry Historical Constructions. Classical and Advanced Approaches. Archives of Computational Methods in Engineering, 17(3): 299-325, doi: http://dx.doi. org/10.1007/s11831-010-9046-1.

(6) ICOMOS. (2003). Recommendations for the analysis, conservation and structural restoration of architectural heritage. http://www.international.icomos.org/charters/structures_e.pdf.

(7) Lourenço, P. B. (2005). Assessment, diagnosis and strengthening of Outeiro Church, Portugal. Construction and Buildings Materials, 19(8): 634-645, doi: http://dx.doi.org/10.1016/j.conbuildmat.2005.01.010.

(8) González Rodríguez, R., Aguilar Moya, L., Martín Mochales, D., Barrionuevo Contreras, F., Collado Moreno, M. (2008). Carta arqueológica municipal: Jerez 1: El núcleo urbano, p. 71. Sevilla: Consejería de Cultura, Junta de Andalucía.

(9) Grandallana y Zapata, L. (1885). Noticia Histórico-artística de algunos de los principales monumentos de Jerez, ilustrada con noticias inéditas, p. 21. Jerez: Gautier.

(10) García Peña, C. (1990). Arquitectura gótica religiosa en la provincia de Cádiz: diócesis de Jerez. (PhD Thesis). Madrid: Complutense University of Madrid.

(11) Aroca Vicenti, F. (2002). Arquitectura y urbanismo en el Jerez del siglo XVIII, p. 210-225. Jerez: Centro Universitario de Estudios Sociales.

(12) Ríos Martínez, E. (2003). Antón Martín Calafate y Diego Moreno Meléndez en la arquitectura jerezana del siglo XVII, p. 21, 220, 243. Cádiz: Universidad de Cádiz. Universidad de Sevilla. Servicio de Publicaciones.

(13) Barrios Padura, A., Barrios Sevilla, J., García Navarro, J. (2011). Bearing diagnosis of Santiago Church (Jerez de la Frontera, Spain). Construction and Building Materials, 25(5): 2519-2527, http://dx.doi.org/10.1016/j.conbuildmat.2010.11.090.

(14) Rodríguez Mayorga, E. (2011). Rehabilitación del Templo Parroquial de Santiago Apóstol en Jerez de la Frontera: anamnesis, diagnosis, terapia y control. Sevilla: University of Sevilla.

(15) Binda, L., Saisi, A., Tiraboschi, C. (2001). Application of Sonic Tests to the Diagnosis of Damaged and Repaired Structures. International Journal Non-Destructive Testing and Evaluation, NDT\& E. Int, 34(2): 123-138, doi: http://dx.doi. org/10.1016/So963-8695(00)00037-2.

(16) Heyman, J. (1996). Arches, vaults and buttresses: masonry structures and their engineering. Aldershot, Hampshire: Ashgate Publishing.

(17) Mas Guindal, A. (2005). La concepción estructural de la fábrica en la arquitectura. Informes de la Construcción, 56(496): 3-12, doi: http://dx.doi.org/10.3989/ic.2005.v57.i496.458.

(18) Medianero Hernández, J. M. (1996, 19-21 September). La pervivencia del arbotante como elemento constructivo emblemático en la arquitectura bajoandaluza e hispanoamericana. In Primer Congreso Nacional de Historia de la Construcción (pp. 361-367). Madrid: Ed. A. de las Casas. 
(19) ANSYS $®$ Multiphysics ${ }^{\mathrm{TM}}$. Academic Research, release 15. http://www.ansys.com. ANSYS, Inc.

(20) Lourenço, P. B. (2001, 7-9 November). Analysis of historical constructions: from thrust-lines to advanced simulations. In III International Seminar Historical Constructions. Possibilities of numerical and experimental techniques (pp. 91116). Guimarães: Ed P. B. Lourenço and P. Roca.

(21) Betti, M., Orlando, M., and Vignoli, A. (2011). Static behaviour of an Italian Medieval Castle: Damage assessment by numerical modelling. Computers \& Structures, 89(21-22): 1956-1970, doi: http://dx.doi.org/10.1016/j.compstruc.2011.05.022.

(22) Rodríguez-Mayorga, E., Yanes, E., Compán, V., Sáez, A. (2013). La restauración del templo parroquial de San Dionisio (Jerez de la Frontera, España). La inyección como método de reparación de estructuras de fábrica. Informes de la Construcción, 65(529): 5-16, doi: http://dx.doi.org/10.3989/ic.11.130.

(23) Binda, L., Modena, C., Baronio, G. (1993, 6-9 June). Strengthening of masonries by injection technique. In Proceedings of the Sixth North American Masonry Conference (1-14). Philadelphia: Ed. A. A. Hamid.

(24) Vintzileou, E., Tassios, P. (1995). Three-leaf masonry strengthened by injection cement grouts. Journal of structural Engineering ASCE, 121(5): 848-856, doi: http://dx.doi.org/10.1061/(ASCE)o733-9445(1995)121:5(848).

(25) Van Rickstal, F. (2000). Grout injection of masonry, scientific approach and modelling (PhD Thesis). Leuven: Catholic University of Leuven.

(26) Toumbakari, E. (2002). Lime-pozzolan-cement grouts and their structural effects on composite masonry walls (PhD Thesis). Leuven: Catholic University of Leuven.

(27) Santos, A. (1997). Inyecciones de impregnación y de fracturación. In Curso sobre técnicas generales de refuerzo del terreno y sus aplicaciones. Madrid: CEDEX, Ministerio de Fomento.

(28) Da Casa, F., Echeverría, E., Celis, F. (2007). La intervención bajo rasante, la importancia de su conocimiento. La técnica de la inyección armada. Informes de la Construcción, 59(505): 21-35, doi: http://dx.doi.org/10.3989/ic.2007.v59. i505.498. 